\title{
Suction Cup Samplers for Estimating Nitrate-Nitrogen in Soil Water in Irrigated Sugarbeet Production
}

\author{
Jay D. Jabro, William B. Stevens, William M. Iversen, Brett L. Allen, Upendra M. Sainju \\ USDA-ARSNorthern Plains Agricultural Research Laboratory, Sidney, MT, USA \\ Email: jay.jabro@ars.usda.gov
}

How to cite this paper: Jabro, J.D., Stevens, W.B., Iversen, W.M., Allen, B.L. and Sainju, U.M. (2016) Suction Cup Samplers for Estimating Nitrate-Nitrogen in Soil Water in Irrigated Sugarbeet Production. Journal of Environmental Protection, 7, 1342-1354. http://dx.doi.org/10.4236/jep.2016.710117

Received: July 29, 2016

Accepted: September 25, 2016

Published: September 29, 2016

\begin{abstract}
Efforts have increased to measure nitrate losses from farmland under different management practices due to environmental and public concerns over levels of nitratenitrogen $\left(\mathrm{NO}_{3}-\mathrm{N}\right)$ in surface and ground waters. This study evaluated the effect of conventional tillage (CT) and strip tillage (ST) practices and three $\mathrm{N}$ application rates on $\mathrm{NO}_{3}-\mathrm{N}$ concentrations in soil water at a $76 \mathrm{~cm}$ depth under irrigated sugarbeet (Beta vulgaris L.) in a clay loam soil. Nitrogen rates were applied as dry urea at $120,150,180 \mathrm{~kg} \mathrm{~N} \mathrm{ha}^{-1}$ in 2006; 130, 160, $190 \mathrm{~kg} \mathrm{~N} \mathrm{ha}^{-1}$ in 2007; and 110, 140, $170 \mathrm{~kg}$ $\mathrm{N} \mathrm{ha}^{-1}$ in 2008. Soil water volumes were measured weekly during each growing season using three ceramic suction cup samplers per plot placed at a $76 \mathrm{~cm}$ depth below the soil surface under each tillage. Results indicated that $\mathrm{NO}_{3}-\mathrm{N}$ concentrations at the $76 \mathrm{~cm}$ depth in the soil profile were not significantly affected by either tillage practice or by $\mathrm{N}$ application rate due to soil variability across the field and due to suction cup samplers' biased estimate of soil water. The three $\mathrm{N}$ rates under $\mathrm{CT}$ and ST practices maintained $\mathrm{NO}_{3}-\mathrm{N}$ concentrations below the root zone to levels exceeding the $10 \mathrm{mg}$ $\mathrm{L}^{-1}$ safe drinking water maximum level in all three years. There were large variations in $\mathrm{NO}_{3}-\mathrm{N}$ concentrations among replicates within each tillage and $\mathrm{N}$ rate that were likely caused by variability in soil physical, hydraulic and chemical properties that impacted water movement through the soil profile, $\mathrm{N}$ dynamics and leaching below the root zone of sugarbeet. In conclusion, suction cup samplers are point water measurement devices that reveal considerable variability among replicates within each treatment due to the heterogeneity of field soils. Further, these samplers are not recommended in heterogeneous soils with preferential flow characteristics.
\end{abstract}

\section{Keywords}

Suction Cup Samplers, Nitrate-Nitrogen, Sugarbeet, Strip Tillage, Conventional Tillage 


\section{Introduction}

Contamination of surface and ground waters with nitrate-nitrogen $\left(\mathrm{NO}_{3}-\mathrm{N}\right)$ from farmland is a major environmental issue and an important public health concern. Nitrate- $\mathrm{N}$ levels at and above $10 \mathrm{mg} \mathrm{L}^{-1}$ have been shown to pose health risks to humans and particularly to infants, causing a condition called methemoglobinemia [1]. Consequently, the United States Environmental Protection Agency [2] has designated the maximum contamination limit for $\mathrm{NO}_{3}-\mathrm{N}$ in drinking water at $10 \mathrm{mg} \mathrm{L}^{-1}(10 \mathrm{ppm})$. This issue has received increasing attention nationally and internationally over the past several decades. With these growing public and environmental concerns, researchers are diligently working to develop farm management practices that will reduce $\mathrm{NO}_{3}-\mathrm{N}$ leaching loss from agricultural production lands.

Nitrogen $(\mathrm{N})$ in soil is dynamic and is susceptible to leaching, denitrification, volatilization, and immobilization processes within the soil ecosystem. Nitrate-N leaching losses from agricultural production depends on $\mathrm{N}$ fertilizer application practices, soil type, tillage systems, $\mathrm{N}$ transformations due to changes in the soil ecosystem and irrigation practices.

The effect of tillage on $\mathrm{NO}_{3}-\mathrm{N}$ leaching is viewed by many researchers as a controversial matter. Research has shown higher $\mathrm{NO}_{3}-\mathrm{N}$ leaching losses under conventional tillage due to increased $\mathrm{N}$ mineralization [3] [4].

Randall and Iragavarapu [4] found that average flow-weighted $\mathrm{NO}_{3}-\mathrm{N}$ concentrations were 13.4 and $12.0 \mathrm{mg} \mathrm{L}^{-1}$ for conventional and no-tillage practices, respectively, under corn (Zea mays L.) production. Although the differences were small, their results suggested a trend toward greater $\mathrm{NO}_{3}-\mathrm{N}$ leaching losses with conventional tillage than no-tillage in their 6-yr study. Conversely, other researchers reported higher $\mathrm{NO}_{3}-\mathrm{N}$ leaching losses with no-tillage as compared to tillage due to an increase in soil infiltration rate and internal drainage under no-tillage practices [5]-[7]. Other researchers have found little evidence of a relationship between tillage practices and risk of nitrate leaching. Randall and Mulla [8] concluded that nitrate leaching losses from agricultural fields is minimally affected by different tillage practices compared with $\mathrm{N}$ management practices. Al-Kaisi and Licht [9] concluded in a 2-yr study that strip tillage, chisel plow, and no-tillage systems did not cause significant differences in $\mathrm{NO}_{3}-\mathrm{N}$ concentration in water leachate collected at the $1.2 \mathrm{~m}$ depth in loam and silty clay loam soils in corn.

Nitrogen fertilizer application rate is one of the primary causes of nitrate losses to surface and ground waters. Therefore implementing better and more site-specific $\mathrm{N}$ and irrigation management practices with an appropriate tillage system is essential to minimize nitrate leaching to the environment from fertilized farms while sustaining crop productivity. Zvomuya et al. [10] compared the effect of 140 and $280 \mathrm{~kg} \mathrm{~N}^{-1}$ rates on potato yield and $\mathrm{NO}_{3}-\mathrm{N}$ leaching on a loamy sand soil. In their 3-yr study, they found that nitrate leaching increased rapidly with increased fertilizer $\mathrm{N}$ application rate on coarse-textured soils.

Little is known about the effects of different tillage systems, particularly, the strip tillage practice in conjunction with $\mathrm{N}$ input rates on $\mathrm{NO}_{3}-\mathrm{N}$ concentration below the root 
zone under irrigated sugarbeet production in the northern Great Plains (NGP) region. We hypothesized that 1) strip tillage would reduce the leached amounts of $\mathrm{NO}_{3}-\mathrm{N}$ compared to conventional tillage due to immobilization process of soil $\mathrm{N}$ (not measured) in ST plots as a result of presence of crop residue, and 2) a positive correlation would exist between $\mathrm{N}$ input rates and amounts of $\mathrm{NO}_{3}-\mathrm{N}$ leached below the root zone of irrigated sugarbeet under a given tillage system. Therefore the objective of this study was to evaluate and compare the effect of conventional tillage (CT) and strip tillage (ST) practices and three $\mathrm{N}$ input rates on $\mathrm{NO}_{3}-\mathrm{N}$ concentrations in soil water measured by suction cup samplers below the root zone of sugarbeet under irrigated conditions in a clay loam soil.

\section{Materials and Methods}

\subsection{Experimental Layout and Field Methods}

A 3-yr field study was established in spring 2006 at the Montana State University, Eastern Agricultural Research Center (EARC) located in Sidney, MT, USA (latitude 47.7255 $\mathrm{N}$, longitude 104.1514 W, elevation $650 \mathrm{~m}$ ). The field site is on a Savage clay loam (fine, smectitic, frigid VerticArgiustoll). The experimental location consists of deep welldrained soil formed in alluvial parent material, and is nearly level ( $<1 \%$ slope). The amount of soil organic matter in the upper $30 \mathrm{~cm}$ averaged $2.67 \%$ with a $\mathrm{CV}=34.9 \%$ $(\mathrm{n}=24)$.

Two cropping system treatments were implemented, namely CT-sugarbeet/CTmalting barley and ST-sugarbeet/CT-malting barley with each phase of each rotation present each year. Sugarbeet was planted following malting barley (Hordeum vulgare L.) in each of the three study years and all barley residues remained on the field following barley harvest. Nitrate-N concentrations in soil water were monitor the sugarbeet phase of the rotation only.

Plots were irrigated with a self-propelled overhead linear-move sprinkler irrigation system (Valmont Industries, Inc., Valley, NE, USA) fitted with mid-elevation spray application (MESA) heads (Rotator with D6-12 ${ }^{\circ}$ R3000 plate, Nelson, Walla Walla, WA, USA) suspended about $1 \mathrm{~m}$ above the sugarbeet canopy, spaced $3 \mathrm{~m}$ apart that delivered water at approximately $24 \mathrm{~L} \mathrm{~min}^{-1} \mathrm{head}^{-1}$. Total amounts of seasonal rainfall were 194, 227, and $142 \mathrm{~mm}$ in 2006, 2007, and 2008 growing seasons, respectively. Total irrigation amounts applied to sugarbeet plots during 2006, 2007, and 2008 growing season were $212.3,284.5$, and $270.8 \mathrm{~mm}$, respectively. The amount of water lost by evaporation from soil surface and transpiration from the sugarbeet plants (evapotraspiration, ET) were 553.9, 640.8, and $587 \mathrm{~mm}$ for the 2006, 2007, and 2008 growing seasons, respectively.

\subsection{Tillage Practices Description}

Conventional tillage consisted of six separate operations using different implements following the harvest of malt barley. Plots were fertilized, disked $12 \mathrm{~cm}$ deep and then tilled with a soil ripper (Case IH, Racine, WI, USA) to a depth of $30 \mathrm{~cm}$. Conventional 
tillage was completed by making two passes with a rolling mulcher (Brillion Inc., Brillion, WI), and two passes with a leveler (Eversman, Denver, CO, USA).

Strip tillage was performed using a single operation with a modified ST machine (SchlagelMfg, Torrington, WY, USA) that provided alternating $30-\mathrm{cm}$ wide strips of tilled and untilled soil. The ST implement also applied fertilizer in a band in the center of the tilled zone. Strip tillage and the associated fertilizer application were performed in the fall of previous year.

The preceding malt barley crop was harvested in August of each year using a combine harvester equipped with straw spreaders that uniformly distributed chaff and straw across each plot under both CT and ST systems. Dates of sugarbeet planting were 01 May 2006, 23 April 2007, and 25 April 2008. Dates of sugarbeet hand harvest were 21 September, 2006, 27 September 2007, and 26 September 2008.

Further information regarding tillage operations and dates, fertilizer applications and dates, irrigation system and experimental design were described in detail by Evans et al. [11] [12]; Stevens et al. [13] and Jabro et al. [14].

\subsection{Fertilizer Application Rate}

Urea and mono-ammonium phosphate were applied based on soil test results estimated on composite soil samples collected the fall preceding the sugarbeet crop. Nitrogen was applied as dry urea at $120,150,180 \mathrm{~kg} \mathrm{~N} \mathrm{ha}^{-1}$ in 2006; 130, 160, $190 \mathrm{~kg} \mathrm{~N}^{-1}$ in 2007; and $110,140,170 \mathrm{~kg} \mathrm{~N} \mathrm{ha}^{-1}$ in 2008 with the middle rate representing the recommended $\mathrm{N}$ application for each year. Monoammonium phosphate was applied at $56 \mathrm{~kg} \mathrm{P}_{2} \mathrm{O}_{5}$ $\mathrm{ha}^{-1}$. The same amount of $\mathrm{N}$ and P fertilizer was applied to both CT and ST treatments. Fertilizer was broadcast and incorporated into the top $7.5 \mathrm{~cm}$ of soil on CT plots and was banded about $7.5 \mathrm{~cm}$ under the seed row on ST plots as described by Stevens et al. [13]. Dates of tillage and fertilizer applications were 13 September 2005, 13 September 2006, and 4 September 2007 for 2006, 2007, and 2008 growing seasons, respectively.

\subsection{Description of Ceramic Suction Cup Samplers, Soil Water Sampling and Processing}

Soil water volumes were measured weekly during the growing season using three ceramic suction cup water samplers per plot placed at a $76 \mathrm{~cm}$ depth below the soil surface under each tillage system. Suction cup samplers were located in the fourth crop row (61-cm row spacing) from each respective plot edge [14]. Suction cup water samplers or lysimeters consisted of a cylindrical porous ceramic cup $(20 \mathrm{kPa}$ high flow model with an outside diameter of $4.826 \mathrm{~cm}$, inner diameter of $4.034 \mathrm{~cm}$ and $6.045 \mathrm{~cm}$ long) sealed to the lower end of a polyvinyl chloride (PVC) pipe using epoxy glue (Soilmoisture Equipment Corp, Goleta, CA, USA). The surface area of the ceramic cup in contact with the soil was approximately $74.74 \mathrm{~cm}^{2}$. The total PVC tubing length including the ceramic cup was approximately $88 \mathrm{~cm}$. Two small polypropylene tubes were inserted through a size 10 rubber stopper in the above-ground end of each PVC tube. The long tube was extended to the base of the ceramic cup to extract the volume of drainage soil water (soil solution). The short tube, which consists of a $15 \mathrm{~cm}$ long rigid 
tube with a vacuum hose attached on the outside of the rubber stopper, was used to apply vacuum. Holes $5.08 \mathrm{~cm}$ in diameter were drilled into the soil to a depth of $85 \mathrm{~cm}$ using a truck-mounted probe. Mud slurry was poured into each hole prior to vertical insertion of a suction cup sampler to ensure good cup-to-soil contact. Any space along the outside of the water sampler casing was sealed with soil slurry to prevent preferential flow along the sides [14].

Samples of soil water were collected by creating a partial vacuum of $-50 \mathrm{kPa}$ with a hand operated syringe connected to the smaller inside tube. Soil water samples were stored in an ice cooler. The volume of soil water in each container was later measured in the laboratory, where a small soil water sample was filtered using Q2 filter paper (porosity: fine, flow rate: slow; Fisher Scientific, Pittsburgh, PA, USA), then stored frozen in a small container until analyzed for $\mathrm{NO}_{3}-\mathrm{N}$ using an automated flow analyzer (QuikChem 8000; Lachat Instruments, Milwaukee, WI, USA).

Suction cup samplers were reinstalled each year after planting then removed prior to harvest each year.

Seasonal average $\mathrm{NO}_{3}-\mathrm{N}$ concentration in soil water $(\overline{C N})$ values for each replication or plot under each $\mathrm{N}$ rate and tillage practices were calculated as:

$$
\overline{C N}=\frac{\sum_{i}^{n} C N i}{n}
$$

where $\mathrm{CN} i$ is concentration of $\mathrm{NO}_{3}-\mathrm{N}\left(\mathrm{mg} \mathrm{L}^{-1}\right)$ in the soil water sample for each sampling interval or week, $i, i=1,2,3, \cdots, \mathrm{n}$ that corresponds to sampling events which were 14,10 , and 11 for 2006, 2007, and 2018, respectively.

\subsection{Soil Physical and Hydraulic Properties}

Particle size distribution for each soil sample was determined using the hydrometer method. Mean and coefficient of variation (CV \%) results of sand, silt, and clay in the soil are given in Table 1 .

Table 1. Mean soil particle size distribution and coefficient of variation (CV, \%) at $0-10,10-20$, 20 - 40, and 40 - $60 \mathrm{~cm}$ depths for Savage clay loam soil.

\begin{tabular}{cccccc}
\hline Depth $(\mathrm{cm})$ & Statistics $^{\mathrm{a}}$ & Sand & Silt & Clay & Textural class \\
\hline $0-10$ & Mean & 21 & 42 & 37 & Clay Loam \\
& CV (\%) & 29 & 5 & 16 & \\
$10-20$ & Mean & 19 & 44 & 37 & Silty Clay Loam \\
& CV (\%) & 41 & 5 & 17 & \\
$20-40$ & Mean & 12 & 49 & 39 & Silty Clay Loam \\
& CV (\%) & 10 & 20 & 26 & Silty Clay \\
\hline
\end{tabular}

${ }^{\mathrm{a}}$ Number of observations is 12 . 
Undisturbed soil samples were collected using a stainless steel core of $50 \mathrm{~mm}$ internal diameter and $50 \mathrm{~mm}$ length from each plot at $0-10,10-20$, and $20-30 \mathrm{~cm}$ depths under CT and ST practices in 2007. Soil cores were used to measure bulk density as mass of oven dried soil per volume of core $\left(\mathrm{Mg} \mathrm{m}^{-3}\right)$ and gravimetric moisture content as mass of water in the soil sample per mass of the oven dried soil $\left(\mathrm{g} \mathrm{g}^{-1}\right)$. Soil cores were extracted from within the crop row for each tillage treatment (Table 2).

Soil saturated hydraulic conductivity (Kfs) measurements for the surface layer (0 - 10 $\mathrm{cm}$ ) were determined using the single head pressure ring infiltrometer method [15] while Kfs measurements for the two subsurface layers $(10-20,20-30 \mathrm{~cm})$ were assessed using a constant head well permeameter [16]. Soil Kfs measurements were made within the row of sugarbeet at each layer for each tillage treatment (Table 2). Soil cores

Table 2. Mean and coefficient of variation (CV) of soil bulk density (BD), moisture content (MC), and saturated conductivity (Kfs) at $0-10,10-20$, and $20-30 \mathrm{~cm}$ depths for Savage clay loam soil under conventional (CT) and strip tillage (ST) practices near Sidney, MT, 2006.

\begin{tabular}{|c|c|c|c|c|}
\hline Tillage & Depth, cm & Soil Property ${ }^{\mathrm{a}}$ & Mean & $\mathrm{CV}(\%)$ \\
\hline \multicolumn{5}{|l|}{$\mathrm{CT}$} \\
\hline & $0-10$ & & & \\
\hline & & $\mathrm{BD}\left(\mathrm{Mg} \mathrm{m}^{-3}\right)$ & 1.405 & 6.5 \\
\hline & & $\mathrm{MC}\left(\mathrm{g} \mathrm{g}^{-1}\right)$ & 0.205 & 4.0 \\
\hline & & $\mathrm{Kfs}\left(\mathrm{mm} \mathrm{h}^{-1}\right)$ & 37.20 & 104.5 \\
\hline & $10-20$ & & & \\
\hline & & $\mathrm{BD}\left(\mathrm{Mg} \mathrm{m}^{-3}\right)$ & 1.520 & 4.9 \\
\hline & & $\mathrm{MC}\left(\mathrm{g} \mathrm{g}^{-1}\right)$ & 0.219 & 9.5 \\
\hline & & $\mathrm{Kfs}\left(\mathrm{mm} \mathrm{h}^{-1}\right)$ & 4.86 & 97.9 \\
\hline & $20-30$ & & & \\
\hline & & $\mathrm{BD}\left(\mathrm{Mg} \mathrm{m}^{-3}\right)$ & 1.49 & 6.1 \\
\hline & & $\mathrm{MC}\left(\mathrm{g} \mathrm{g}^{-1}\right)$ & 0.215 & 9.6 \\
\hline \multirow[t]{13}{*}{ ST } & & $\mathrm{Kfs}\left(\mathrm{mm} \mathrm{h}^{-1}\right)$ & 8.28 & 166.6 \\
\hline & $0-10$ & & & \\
\hline & & $\mathrm{BD}\left(\mathrm{Mg} \mathrm{m}^{-3}\right)$ & 1.324 & 2.9 \\
\hline & & $\mathrm{MC}\left(\mathrm{g} \mathrm{g}^{-1}\right)$ & 0.224 & 7.2 \\
\hline & & $\mathrm{Kfs}\left(\mathrm{mm} \mathrm{h}^{-1}\right)$ & 76.21 & 58.5 \\
\hline & $10-20$ & & & \\
\hline & & $\mathrm{BD}\left(\mathrm{Mg} \mathrm{m}^{-3}\right)$ & 1.433 & 3.6 \\
\hline & & $\mathrm{MC}\left(\mathrm{g} \mathrm{g}^{-1}\right)$ & 0.249 & 6.0 \\
\hline & & $\mathrm{Kfs}\left(\mathrm{mm} \mathrm{h}^{-1}\right)$ & 3.524 & 105.8 \\
\hline & $20-30$ & & & \\
\hline & & $\mathrm{BD}\left(\mathrm{Mg} \mathrm{m}^{-3}\right)$ & 1.437 & 5.3 \\
\hline & & $\mathrm{MC}\left(\mathrm{g} \mathrm{g}^{-1}\right)$ & 0.241 & 5.3 \\
\hline & & $\mathrm{Kfs}\left(\mathrm{mm} \mathrm{h}^{-1}\right)$ & 8.414 & \\
\hline
\end{tabular}

${ }^{a}$ Number of observations (n) per treatment and per each depth is 4 . 
and $\mathrm{Kfs}$ measurements were taken within approximately $1 \mathrm{~m}$ of the suction cup water samplers.

\subsection{Statistical Analysis}

The experimental design was a randomized complete block with individual main 14.6 $\mathrm{m} \times 24.4 \mathrm{~m}$ plots arranged as a split plot with eight replications in 2006 and 2008 and six replications in 2007. Sub plots $(3.7 \times 12.2 \mathrm{~m})$ were arranged randomly within the outer margins of the main plots. Nitrate- $\mathrm{N}$ data were analyzed using the SAS mixed model procedure [17]. Method of tillage was treated as fixed main plot effect, with $\mathrm{N}$ rate as a fixed split plot effect and replication as the random effect. All statistical comparisons were performed at $\mathrm{P}<0.05$.

\section{Results and Discussion}

\subsection{Effect of Tillage}

Seasonal average $\mathrm{NO}_{3}-\mathrm{N}$ concentrations in soil water below a $76 \mathrm{~cm}$ depth under sugarbeet did not differ significantly between $\mathrm{CT}$ and ST practices for all three $\mathrm{N}$ application rates in 2006,2007 , and 2008 , respectively, due to considerable variability in soil physical and hydraulic properties among plots (Figures 1-3). There were large variations in $\mathrm{NO}_{3}-\mathrm{N}$ concentrations among replicates or plots under each tillage for each $\mathrm{N}$ rate treatment used in this study as are indicated by two standard errors of the mean and displayed in Figures 1-3 for 2006, 2007, and 2008, respectively. The spatial variability in the field's soil among replicates within each tillage treatment had a major impact on soil physical and chemical properties that influenced water movement, $\mathrm{N}$ dynamics, transformation and leaching.

To explain variation among plots within each tillage treatment some possible reasons were considered. Soil across the field was not uniform but rather was heterogeneous

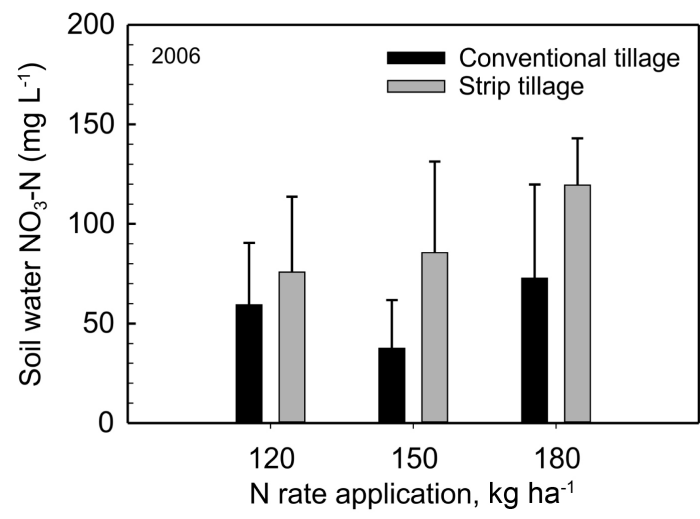

Figure 1. Effect of conventional tillage (CT) and strip tillage (ST) on average seasonal $\mathrm{NO}_{3}-\mathrm{N}$ concentration at a $76 \mathrm{~cm}$ depth under 120,150 , and $180 \mathrm{~kg} \mathrm{~N} \mathrm{ha}^{-1}$ application rates in sugarbeet near Sidney, MT, 2006. Error bars represent two standard errors of the mean. 


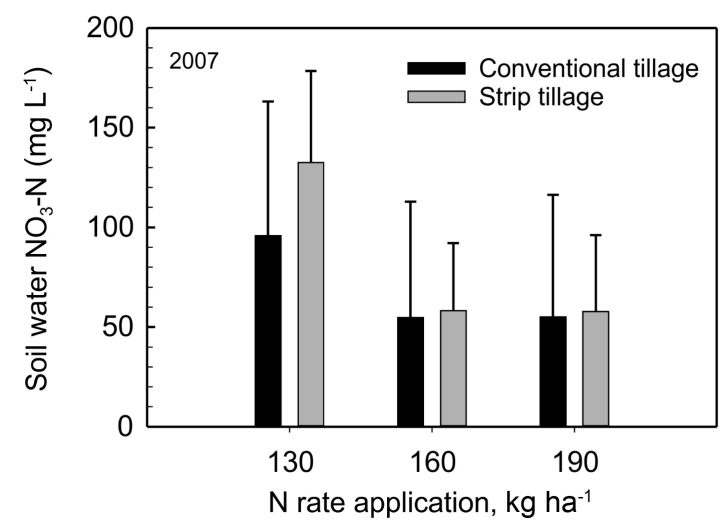

Figure 2. Effect of conventional tillage (CT) and strip tillage (ST) on average seasonal $\mathrm{NO}_{3}-\mathrm{N}$ concentration at a $76 \mathrm{~cm}$ depth under 120,150 , and $180 \mathrm{~kg} \mathrm{~N} \mathrm{ha}^{-1}$ application rates in sugarbeet near Sidney, MT, 2007. Error bars represent two standard errors of the mean.

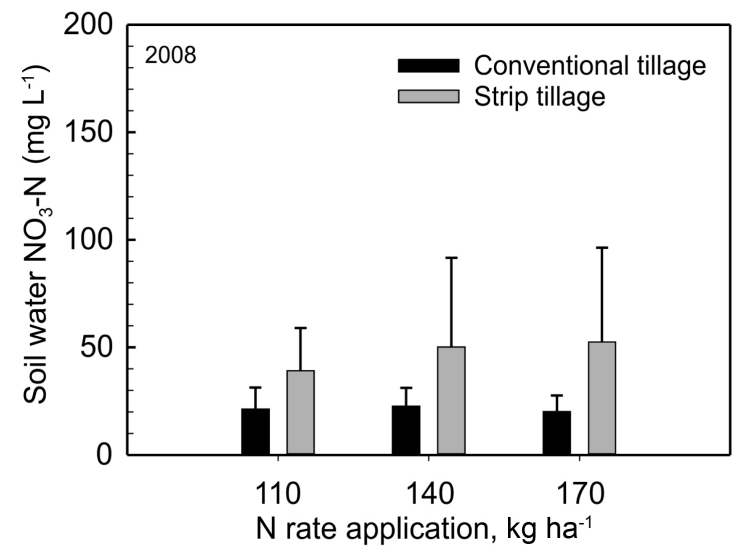

Figure 3. Effect of conventional tillage (CT) and strip tillage (ST) on average seasonal $\mathrm{NO}_{3}-\mathrm{N}$ concentration at a $76 \mathrm{~cm}$ depth under 120,150 , and $180 \mathrm{~kg} \mathrm{~N} \mathrm{ha}^{-1}$ application rates in sugarbeet near Sidney, MT, 2008. Error bars represent two standard errors of the mean.

and exhibited great spatial variability in soil physical and hydraulic properties among plots within each tillage treatment (Table 1 and Table 2). Most soil properties which influence the transport of $\mathrm{NO}_{3}-\mathrm{N}$ through natural field soils varied substantially at different locations, even at short separation distances (Table 1 and Table 2). For instance, soil Kfs measurements in Table 2 showed large spatial variation among plots under each tillage practice attributed to variability in soil morphology in the field. The variability of soil Kfs among plots within the study site was classified as high (CV > 75\%) under both tillage systems according to classification described by Dahiya et al. [18].

Research conducted on Savage clay loam soils showed that these soils exhibited cracks and a high potential of preferential water flow throughout the soil profile [19]. Therefore, another reason for inconsistency of suction cup samplers for measuring 
$\mathrm{NO}_{3}-\mathrm{N}$ concentration in soil water among replicates within each treatment was related to preferential flow that mainly affected water movement and nitrate transport through cracks and worm holes that bypassed most of the soil matrix (microporous medium) and ceramic cups directly to the lower portion of the soil profile in the Savage clay loam used in this study [19].

The effect of tillage on water movement into and through the soil profile is inconsistent as both CT and ST practices can either increase or decrease Kfs [20] [21]. Changes in soil Kfs across a field and among plots within the same tillage treatment can affect water movement, which in turn affects $\mathrm{NO}_{3}-\mathrm{N}$ concentrations and transport through the soil profile. Therefore, knowledge of the soil spatial variability across a field is critical to the success of site-specific water and $\mathrm{N}$ management practices.

\subsection{Effect of Nitrogen Application Rate}

Average seasonal $\mathrm{NO}_{3}-\mathrm{N}$ concentrations in soil water below the root zone of sugarbeet from three N application rates under CT and NT practices for 2006, 2007, and 2008 are presented in Figures 4-6, respectively. Statistical results showed that average seasonal $\mathrm{NO}_{3}-\mathrm{N}$ concentrations within $\mathrm{CT}$ and ST practice did not differ significantly among $\mathrm{N}$ rates for all three years. Nitrate- $\mathrm{N}$ concentration exhibited considerable variation among plots within each $\mathrm{N}$ application rate as shown by two standard errors of the mean (Figures 4-6). Our results did not follow the paradigm that $\mathrm{NO}_{3}-\mathrm{N}$ concentrations in the soil profile increase with an increase of $\mathrm{N}$ application rate except in 2006 under ST, though these trends were not significant.

Zvomuya et al. [10] reported that nitrate leaching increased rapidly with increasing fertilizer $\mathrm{N}$ rate on coarse-textured soils. This paradigm may only apply to uniform and coarse textured soils that have homogeneous morphologies but not to heterogeneous field soils, clayey soils, soils with high spatial and vertical variability, and soils with preferential flow patterns and macroporous characteristics.

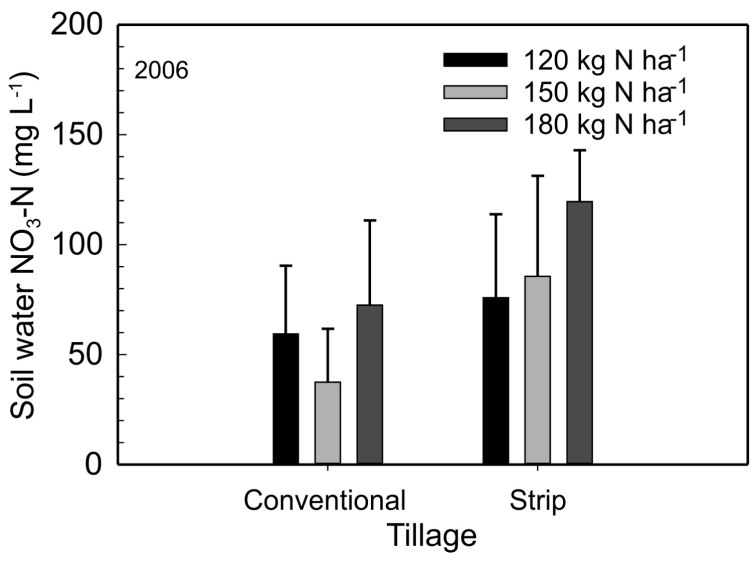

Figure 4. Effect of $\mathrm{N}$ application rates on average seasonal $\mathrm{NO}_{3}-\mathrm{N}$ concentration in soil water at a $76 \mathrm{~cm}$ depth under sugarbeet conventional tillage (CT) and strip tillage (ST) practices in 2006 . 


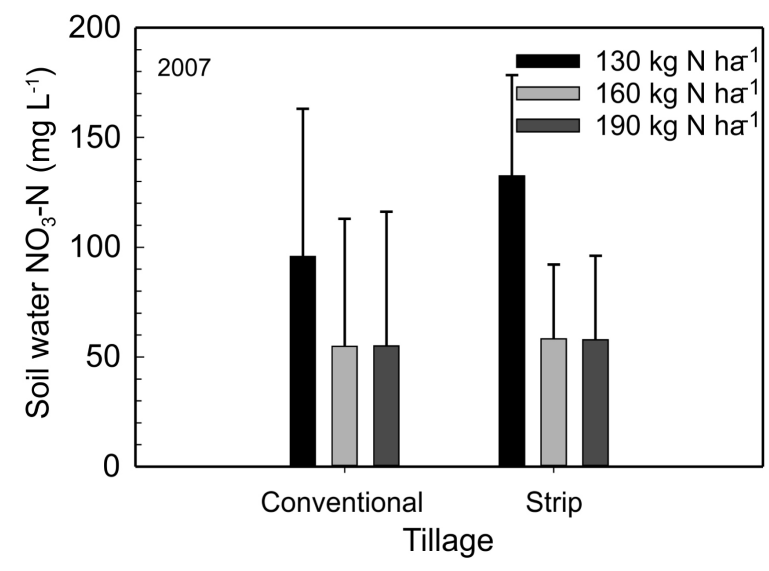

Figure 5. Effect of $\mathrm{N}$ application rates on average seasonal $\mathrm{NO}_{3}-\mathrm{N}$ concentration in soil water at a $76 \mathrm{~cm}$ depth under sugarbeet conventional tillage (CT) and strip tillage (ST) practices in 2007.

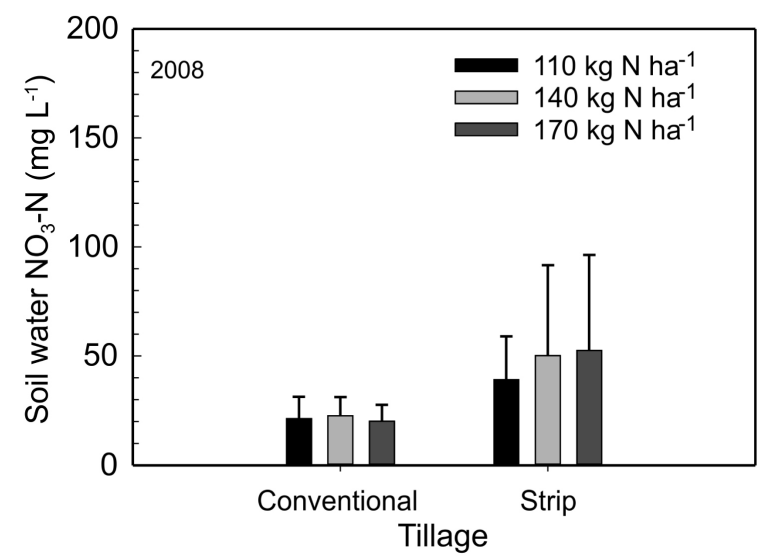

Figure 6. Effect of $\mathrm{N}$ application rates on average seasonal $\mathrm{NO}_{3}-\mathrm{N}$ concentration in soil water at a $76 \mathrm{~cm}$ depth under sugarbeet conventional tillage (CT) and strip tillage (ST) practices in 2008 .

The soil variability among plots for each $\mathrm{N}$ rate likely had an impact on soil physical, chemical and biological properties that influenced water movement, $\mathrm{N}$ dynamics, and $\mathrm{N}$ transformation and losses. Variations in soil texture, internal drainage, water content, and porosity (Table 1 and Table 2) among field plots likely significantly impacted soil temperature and microbial activity which in turn affected soil $\mathrm{N}$ dynamics, $\mathrm{N}$ transformation and leaching.

Another possible reason of variability in $\mathrm{NO}_{3}-\mathrm{N}$ concentration in soil water could be associated with distribution of residue and organic matter from previous crops among plots across the field. Soil $\mathrm{N}$ mineralization tends to be higher in plots with high organic matter which in turn produce higher $\mathrm{NO}_{3}-\mathrm{N}$ transport than plots with lower soil organic matter. The amount of soil organic matter in the upper $30 \mathrm{~cm}$ averaged $2.67 \%$ with a CV $=34.9 \%(n=24)$. The variability of soil organic matter among plots within 
the study site was classified as medium (CV $=15 \%-75 \%)$ according to Dahiya et al. [18].

Another possible factor that contributed to variability of $\mathrm{NO}_{3}-\mathrm{N}$ concentrations in soil water among plots within the same treatment is that $\mathrm{NO}_{3}-\mathrm{N}$ under each tillage system can be moved below the majority of the sugarbeet root zone with excess irrigation regardless of $\mathrm{N}$ application rate. Our overhead linear move sprinkler irrigation is a cutting-edge technology system with a high efficiency of $85 \%$ - $90 \%$ that applies water uniformly over an entire soil surface compared to furrow irrigation. Despite the uniformity of the irrigation system used in this study, some suction cup samplers could have received more water than others that resulted in spatially variable water applications that affected the transport of $\mathrm{NO}_{3}-\mathrm{N}$ by mass flow processes within the soil profile at the $76 \mathrm{~cm}$ depth.

Previous research revealed that suction cup water samplers provided useful data on solute concentration in soil water at various depths within the soil profile [22] [23]. However, those studies indicated that large variations existed in $\mathrm{NO}_{3}-\mathrm{N}$ concentrations in soil water among replications, illustrating the effect of soil variability when using suction cup lysimeters. Wang et al. [23] concluded that suction cups gave inconsistent and biased results of $\mathrm{NO}_{3}-\mathrm{N}$ concentrations in two of three soils used in their study, and they also showed that suction cups only worked well in fairly homogeneous soils.

Our results were in agreement with those summarized by Weihermuller et al. [22] and found by Wang et al. [23] who used suction cup lysimeters for measuring $\mathrm{NO}_{3}-\mathrm{N}$ concentrations in different soil types. Thus, suction cup lysimeters are likely unsuitable for measuring solute concentrations and transport in heterogeneous and heavy clayey soils that show high degrees of variability and preferential flow patterns.

\section{Conclusions}

Seasonal average $\mathrm{NO}_{3}-\mathrm{N}$ concentrations in soil water at the $76 \mathrm{~cm}$ depth under irrigated sugarbeet did not differ significantly between $\mathrm{CT}$ and ST practices for all three $\mathrm{N}$ application rates in 2006, 2007, and 2008 due to soil variability and heterogeneity across the field.

Soil variability among plots within each tillage treatment had a major impact on soil physical, chemical and biological properties that influenced water movement, $\mathrm{N}$ dynamics and concentrations of $\mathrm{NO}_{3}-\mathrm{N}$ in soil water at the $76 \mathrm{~cm}$ depth.

Variations in soil texture, internal drainage, water content, porosity, plant residues and other properties among field plots can significantly impact soil temperature and microbial activity which sequentially affect soil $\mathrm{N}$ dynamics, $\mathrm{NO}_{3}-\mathrm{N}$ concentrations and losses.

The findings from this study concur with those from previous research studies that illustrate the limited capabilities of suction cup lysimeters used for monitoring and quantifying $\mathrm{NO}_{3}-\mathrm{N}$ concentration in soil water at various depths in the profile of heterogeneous soils with preferential flow and macropore characteristics. Further research is needed to evaluate the use of suction cup samplers in a broader range of soil types 
and cropping systems.

The three $\mathrm{N}$ rates used in this study under CT and ST practices for three growing seasons maintained $\mathrm{NO}_{3}-\mathrm{N}$ concentrations in soil water below the root zone to levels exceeding the EPA safe drinking water standard of $10 \mathrm{mg} \mathrm{L}^{-1}$.

\section{Acknowledgements}

The authors wish to express their thanks and appreciation to Dale Spracklin and Amy McGregor for their technical support with constructing, testing, and troubleshooting suction cup samplers, sampling analysis of soil and water, and finally, maintaining the experiment throughout the course of study.

\section{Statement}

Mention of a trademark, vendor or proprietary product does not constitute a guarantee or warranty of the product by the USDA and does not imply its approval to the exclusion of other products that may also be suitable. This type of information is solely provided to assist the reader in better understanding the scope of the research and its results.

\section{References}

[1] Greer, F.R. and Shannon, M. (2005) Infant Methemoglobinemia: The Role of Dietary Nitrate in Food and Water. Pediatrics, 116, 784-790.

http://dx.doi.org/10.1542/peds.2005-1497

[2] US Environmental Protection Agency (1991) National Primary Drinking Water Regulations: Final Rule, 40. CFR Parts 141-143. Federal Register, 56, 3526-3597.

[3] Angle J.S., Gross, C.M., Hill, R.L. and Mcintosh, M.S. (1993) Soil Nitrate Concentrations Under Corn as Affected by Tillage, Manure and Fertilizer Application. Journal of Environmental Quality, 31, 141-147. http://dx.doi.org/10.2134/jeq1993.00472425002200010018x

[4] Randall, G.W. and Iragavarapu, T.K. (1995) Impact of Long-term Tillage Systems for Continuous Corn on Nitrate Leaching to Tile Drainage. Journal of Environmental Quality, 24, 360-366. http://dx.doi.org/10.2134/jeq1995.00472425002400020020x

[5] Shipitalo, J.J. and Edwards, W.M. (1993) Seasonal Patterns of Water and Chemical Movement in Tilled and No-till Column Lysimeters. Soil Science Society of America Journal, 57, 218-223. http://dx.doi.org/10.2136/sssaj1993.03615995005700010038x

[6] Singh, B. and Malhi, S.S. (2006) Response of Soil Physical Properties to Tillage and Residue Management on Two Soils in a Cool Temperate Environment. Soil and Tillage Research, 85, 143-153. http://dx.doi.org/10.1016/j.still.2004.12.005

[7] Meisinger, J.J., Palmer, R.E. and Timlin, D.J. (2015) Effects of Tillage Practices on Drainage and Nitrate Leaching from Winter Wheat in the Northern Atlantic Coastal-Plain USA. Soil Tillage and Tillage Research, 151, 18-27. http://dx.doi.org/10.1016/j.still.2015.02.007

[8] Randall, G.W. and Mulla, D.J. (2001) Nitrate Nitrogen in Surface Waters as Influenced by Climatic Conditions and Agricultural Practices. Journal of Environmental Quality, 30, 337-344. http://dx.doi.org/10.2134/jeq2001.302337x

[9] Al-Kaisi, M. and Licht, M.A. (2004) Effect of Strip Tillage on Corn and Corn Nitrogen Uptake and Residual Soil Nitrate Accumulation Compared with No-tillage and Chisel Plow. Agronomy Journal, 96, 1164-1171. http://dx.doi.org/10.2134/agronj2004.1164 
[10] Zvomuya, F., Rosen, C.J., Russelle, M.P. and Gupta, S.C. (2003) Nitrate Leaching and Nitrogen Recovery Following Application of Polyolefin-Coated Urea to Potato. Journal of Environmental Quality, 32, 480-489. http://dx.doi.org/10.2134/jeq2003.4800

[11] Evans, R.G., Stevens, W.B. and Iversen, W.M. (2010a) Development of Strip Tillage on Sprinkler Irrigated Sugarbeet. Applied Engineering in Agriculture, 26, 59-69.

http://dx.doi.org/10.13031/2013.29476

[12] Evans, R.G., Iversen, W.M., Stevens, W.B. and Jabro, J.D. (2010b) Development of Combined Site Specific MESA and LEPA Methods on a Linear Move Sprinkler Irrigation System. Applied Engineering in Agriculture, 26, 883-895. http://dx.doi.org/10.13031/2013.34951

[13] Stevens, W.B., Evans, R.G., Jabro, J.D. and Iversen, W.M. (2010) Nitrogen Availability for Sugarbeet Affected by Tillage System and Sprinkler Irrigation Method. Agronomy Journal, 102, 1745-1752. http://dx.doi.org/10.2134/agronj2010.0122

[14] Jabro, J.D., Stevens, W.B., Iverson, W.M., Evans, R.G. and Allen, B.L. (2014) Crop Water Productivity of Sugarbeet as Affected by Tillage. Agronomy Journal, 106, 2280-2286. http://dx.doi.org/10.2134/agronj14.0186

[15] Reynolds, W.D. and Elrick, D.E. (2002) Pressure Infiltrometer. In: Dane, J.H. and Topp, G.C., Eds., Methods of Soil Analysis. Part 4. Physical Methods. Soil Science Society of America, Madison, WI, 826-836.

[16] Reynolds, W.D., Elrick, D.E. and Clothier, B.E. (1985) The Constant Head Well Permeameter: Effect of Unsaturated Flow. Soil Science, 139, 172-180. http://dx.doi.org/10.1097/00010694-198502000-00011

[17] SAS Institute (2011) The SAS System for Windows. Version 9.2. SAS Institute. Cary, NC.

[18] Dahiya, I.S., Richter, J. and Malik, R.S. (1984) Soil Spatial Variability: A Review. International Journal of Tropical Agriculture, 2, 1-102.

[19] AbouNajm, M.R., Jabro, J.D., Iversen, W.M., Mohtar, R.H. and Evans, R.G. (2010) New Method for Characterization of 3D Preferential Flow Paths at the Field. Water Resources Research, 46, W02503. http://dx.doi.org/10.1029/2009WR008594

[20] Christensen, N.B., Jones, T.L. and Kauta, G.J. (1994) Infiltration Characteristics under No-Till and Clean-Till Furrow Irrigation. Soil Science Society of America Journal, 58, 1495-1500. http://dx.doi.org/10.2136/sssaj1994.03615995005800050032x

[21] Jabro, J.D., Stevens, W.B., Evans, R.G., Iversen, W.M. (2009) Tillage Effects on Physical Properties in Two Soils of the Northern Great Plains. Applied Engineering in Agriculture, 25, 377-382. http://dx.doi.org/10.13031/2013.26889

[22] Weihermuller, L., Siemens, J., Deurer, M., Knoblauch, S., Rupp, H., Gottein, A. and Putz, T. (2007) In Situ Soil Water Extraction: A Review. Journal of Environmental Quality, 36, 1735-1748. http://dx.doi.org/10.2134/jeq2007.0218

[23] Wang, Q., Cameron, K., Buchan, G., Zhao, L., Zhang, E.H., Smith, N. and Carrick, S. (2012) Comparison of Lysimeters and Porous Ceramic Cups for Measuring Nitrate Leaching in Different Soil Types. New Zealand Journal of Agriculture Research, 55, 333-345. http://dx.doi.org/10.1080/00288233.2012.706224 
Submit or recommend next manuscript to SCIRP and we will provide best service for you:

Accepting pre-submission inquiries through Email, Facebook, LinkedIn, Twitter, etc. A wide selection of journals (inclusive of 9 subjects, more than 200 journals)

Providing 24-hour high-quality service

User-friendly online submission system

Fair and swift peer-review system

Efficient typesetting and proofreading procedure

Display of the result of downloads and visits, as well as the number of cited articles

Maximum dissemination of your research work

Submit your manuscript at: http://papersubmission.scirp.org/

Or contact jep@scirp.org 